\title{
Reliability Evaluation of a Micro Heater and its Application for Automotive Sensors
}

\author{
Takio Kojima Member (NGK Spark Plug Co., Ltd. R\&D Center) \\ Yoshinori Tsujimura Non-member (NGK Spark Plug Co., Ltd. R\&D Center) \\ Takuya Mizuno Member (NGK Spark Plug Co., Ltd. R\&D Center) \\ Yuichi Koyama Non-member (NGK Spark Plug Co., Ltd. R\&D Center) \\ Masahito Kida Non-member (NGK Spark Plug Co., Ltd. R\&D Center) \\ Tessho Yamada Non-member (NGK Spark Plug Co., Ltd. R\&D Center)
}

Keywords : micro heater, reliability, electromigration, air flow meter, air quality sensor

A MEMS heater has the features of ultra low thermal mass and good thermal isolation, which bring quick response and high sensitivity. In Addition, it has a function to detect the bidirectional flow. These features are suitable for automotive air flow sensors. On the other hand, high reliability is required for the micro heater consisting of a very thin diaphragm as an automotive part.

We developed a high durable micro heater for automotive applications and its reliability was evaluated from the mechanical and thermal points of view. The diaphragm consists of thermal- $\mathrm{SiO}_{2}, \mathrm{PE}-\mathrm{SiO}_{2}$ and $\mathrm{LP}-\mathrm{Si}_{3} \mathrm{~N}_{4}$, which has a symmetrical structure to the putted thin $\mathrm{Pt}$ film. The ratio of $\mathrm{PE}-\mathrm{SiO}_{2}$ to LP- $\mathrm{Si}_{3} \mathrm{~N}_{4}$ was optimized. The thickness of the diaphragm is 0.7 $\mu \mathrm{m}$.

As a mechanical evaluation, a pressure loading method to the diaphragm was useful for the design examination and process

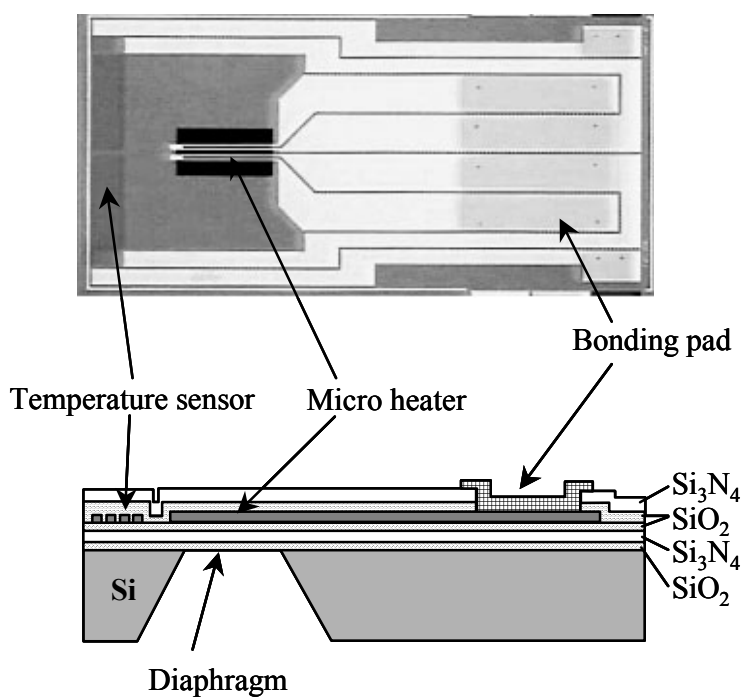

Fig. 1. Photograph and schematic cross section of the micro heater validity.

From the thermal resistant evaluations, the dominant failure modes for instant overheating and longtime heating were found to be de-lamination of the $\mathrm{Pt}$ film and the electromigration of $\mathrm{Pt}$, respectively. The life time was estimated to be over 10 years when the average heater temperature was $400^{\circ} \mathrm{C}$ (the peak temperature was over $600^{\circ} \mathrm{C}$ ) from the following equation.

$$
\begin{aligned}
& M T T F: \text { Mean Time to Failure } \\
& A: \text { Constant } \\
& J: \text { Current density } \\
& n: \text { Current density coefficient } \\
& E_{a}: \text { Activation energy } \\
& k \quad: \text { Boltzmann constant } \\
& T \quad: \text { Temperature }(\mathrm{K})
\end{aligned}
$$

As automotive sensors utilized this micro heater, the developed air flow meter and air quality sensor are described with their features. The unique evaluation methods such as foreign particle collision to the air flow meter are also presented.

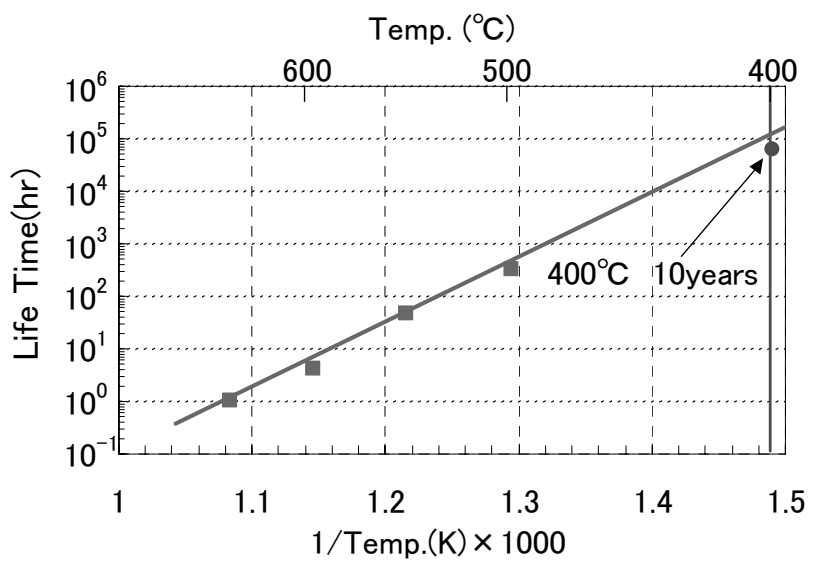

Fig. 2. Arrhenius plots of the micro heater 


\title{
マイクロヒータの信頼性評価と車載用センサへの応用
}

\author{
正 員 小島多喜男* 非会員 辻村 善徳* \\ 正員 水野 卓也* 非会員 神山 雄一* \\ 非会員 喜田 真史 ${ }^{*}$ 非会員 山田 哲正 ${ }^{*}$
}

\author{
Reliability Evaluation of Micro Heater and its Application for Automotive Sensors \\ Takio Kojima*, Member, Yoshinori Tsujimura*, Non-member, \\ Takuya Mizuno*, Member, Yuichi Koyama*, Non-member, \\ Masahito Kida*, Non-member, Tessho Yamada*, Non-member
}

\begin{abstract}
A heat resistant micro heater consisting of a Pt thin film and a diaphragm was developed for automotive sensors and its reliability was evaluated from the mechanical and thermal points of view. The dominant failure modes for instant overheating and longtime heating were found to be de-lamination of the Pt film and electromigration of $\mathrm{Pt}$, respectively. The life time was estimated to be over 10 years when the average heater temperature was $400^{\circ} \mathrm{C}$ (the peak temperature was over $600^{\circ} \mathrm{C}$ ). As automotive sensors utilized this micro heater, the developed air flow meter and air quality sensor are described with features and evaluation methods unique to these sensors.
\end{abstract}

キーワード : マイクロヒータ, 信頼性, エレクトロマイグレーション, エアフローメータ, 空気質センサ

Keywords : micro heater, reliability, electromigration, air flow meter, air quality sensor

\section{1. はじめに}

自動車用の MEMS センサ(1)としては，圧力センサをはじ め加速度センサや角速度センサ等の慣性センサ, 磁気セン サ等が広く使用されているが，近年ではマイクロマシニン グ技術を使って薄膜ダイヤフラム構造を形成し，薄膜部を 局所加熱出来るマイクロヒータを使ったフローセンサ(2)(3) も実用化されつつある。このマイクロヒータを使ったセン サでは, 基板との熱絶縁が高く熱容量が極めて小さいため, 高応答で低消費電力といった大きなメリットが得られる。

一方で厚み数 $\mu \mathrm{m}$ 以下の薄膜構造を有するマイクロヒー 夕を車載用センサに適用する場合, 機械的強度や熱的安定 性において高い信頼性と耐久性が要求される。ダイヤフラ ム構造では主に $\mathrm{SiO}_{2}$ や $\mathrm{Si}_{3} \mathrm{~N}_{4}$ などの絶縁膜から構成されて いるため, 単結晶である $\mathrm{Si}$ そのものを構造体とする MEMS センサに較べ，その信頼性・耐久性は製造プロセスに大き く依存する。そのため, 設計因子の検討だけでなく, 製造 プロセスの妥当性を検証する為にも, マイクロヒータの信 頼性や耐久性を評価する手法を確立する事が重要となる。

\footnotetext{
日本特殊陶業（株）総合研究所

干 485-8510 愛知県小牧市大字岩崎 2808

NGK Spark Plug Co., Ltd. R\&D Center

2808 Iwasaki, Komaki-shi, Aichi 485-8510
}

本稿では，まず開発したマイクロヒータの機械的及び熱 的な信頼性評価の結果について報告し, 更にこのマイクロ ヒータを利用した車載用センサとして, エアフローメータ と空気質センサについてその特徴を示すと共に，アプリケ ーション特有の評価について述べる。

\section{2. マイクロヒータ構造と製造プロセス}

開発した薄膜ダイヤフラム構造を有するフローセンサ用 のマイクロヒータ素子の写真と断面を図 1 に示す。ダイヤ フラムのサイズは長さ $1 \mathrm{~mm}$, 幅 $0.5 \mathrm{~mm}$ で, 厚みは $0.7 \mu \mathrm{m}$ である。ヒータは幅 $20 \mu \mathrm{m}$ で折り返したものを 2 本設けて いる。これは後で述べる順流逆流双方向を検出するフロー センサを想定しているためである。

次に製造プロセスについて述べる。初めに $\mathrm{Si}(100)$ 基板を $0.1 \mu \mathrm{m}$ 熱酸化し, 次に LP-CVDにより $\mathrm{Si}_{3} \mathrm{~N}_{4}$ を $0.2 \mu \mathrm{m}$ 成 膜した後, PE-CVDにより $\mathrm{SiO}_{2}$ を $0.1 \mu \mathrm{m}$ 堆積させ支持膜 を形成した。その上にヒータ材料となる $\mathrm{Pt}$ 薄膜と密着層と なる $\mathrm{Ta}$ 酸化膜をスパッタにて $0.1 \mu \mathrm{m}$ 形成した。アニール 後 $\mathrm{Pt}$ ヒータをパターニングし, パッシベーション膜として $\mathrm{SiO}_{2}$ と $\mathrm{Si}_{3} \mathrm{~N}_{4}$ を各々支持膜と同じ製法, 同じ厚みで成膜し た。この後, 電極用パッドをエッチングで開け $\mathrm{Au}$ 電極を形 成し, 最後にダイヤフラム裏面の絶縁膜をエッチングで開 


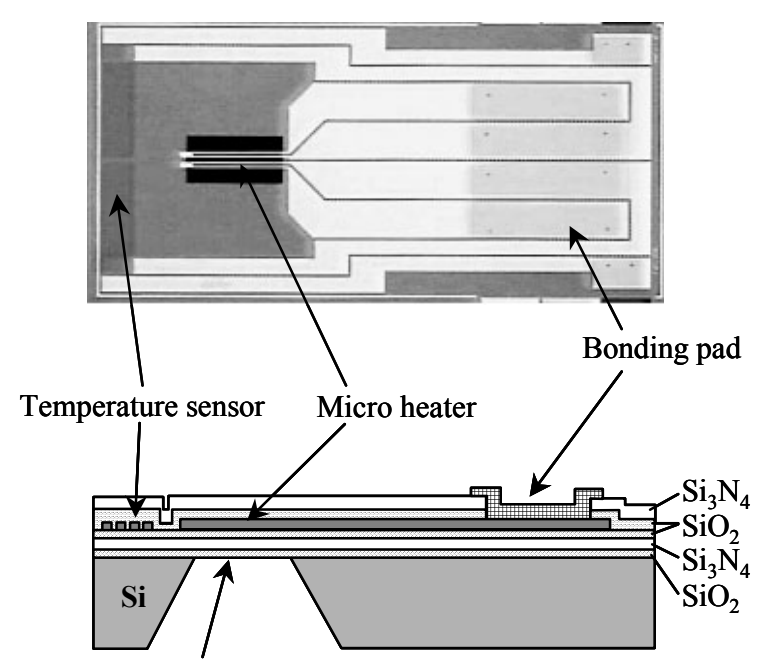

Diaphragm

図 1 マイクロヒータ写真と断面図

Fig. 1. Photograph and schematic cross section of the micro heater.

口し異方性エッチングにて素子裏面から $\mathrm{Si}$ を除去してマイ クロヒータを作製した。尚, Ptの抵抗温度係数 (TCR) は, アニール処理と酸化物密着層の効果により $3600 \mathrm{ppm} /{ }^{\circ} \mathrm{C}$ と 高い值となっている。

\section{3. マイクロヒータの信頼性評価}

〈3·1〉機械的信頼性車載用センサでは, エンジン 振動や車両が路面から受ける振動衝撃に晒されるため, 十 分な機械的強度が必要となる。一般的な評価方法としては 振動試験や衝撃試験があるが，これらの試験は合否を判定 するには良いが，強度差やバラツキを評価するには合理的 でない。また, 振動に対しては共振に対する注意が必要で あるが，マイクロヒータの薄膜ダイヤフラム構造では共振 周波数は通常非常に高く, エンジン振動等で共振振動が発 生する心配は無い。以上より, 静的強度にて評価すること とし, ダイヤフラム上面から圧力を印加して破損耐圧を評 価した。圧力印加式では圧子押し式に較べ, 局所的な偏荷 重が無く簡便に行えるメリットがある。圧力は $0.1 \mathrm{Mpa} こ ゙$ とにステップ状に印加し, 破損するまで行った。

表 1 にダイヤフラム膜の $\mathrm{PE}-\mathrm{SiO}_{2}$ と $\mathrm{Si}_{3} \mathrm{~N}_{4}$ の比率を, 厚 み一定の条件下で各種変更したサンプルでの破損耐圧を示 す。自立膜が形成出来る範囲においては, $\mathrm{Si}_{3} \mathrm{~N}_{4}$ の比率が高 く残留応力が大きな素子の方が高い耐圧強度を示した。こ れは残留応力の影響よりも $\mathrm{Si}_{3} \mathrm{~N}_{4}$ 膜厚みの増加による強度 向上の効果が高いためと推定される。

図 2 に各種製作ロットでの破損耐圧のヒストグラムを示 す。なお，この素子は表 1 とは膜構成が若干異なるもので, チップ単位で試験を行っている。ロットAから C ではほと んど差がないが，プロセス条件を変更したロット D では低 強度となった。これは, その後の調査により RIEのエッチ ング不良であることが判り，RIE の状態を管理することで
表 1 各種ダイヤフラムでの破損耐圧

Table 1. Breaking pressure of various diaphragm.

\begin{tabular}{|c|c|c|c|c|}
\hline Type & $\mathrm{A}$ & $\mathrm{B}$ & $\mathrm{C}$ & $\mathrm{D}$ \\
\hline $\mathrm{SiO}_{2}: \mathrm{Si}_{3} \mathrm{~N}_{4}$ & $4: 1$ & $2: 1$ & $1: 2$ & $1: 5$ \\
\hline $\begin{array}{c}\text { Breaking } \\
\text { pressure }\end{array}$ & $\begin{array}{c}0.6 \\
\mathrm{MPa}\end{array}$ & $\begin{array}{c}0.7 \\
\mathrm{MPa}\end{array}$ & $\begin{array}{c}1.3 \\
\mathrm{MPa}\end{array}$ & $\begin{array}{c}\text { Broken in the } \\
\text { process }\end{array}$ \\
\hline
\end{tabular}

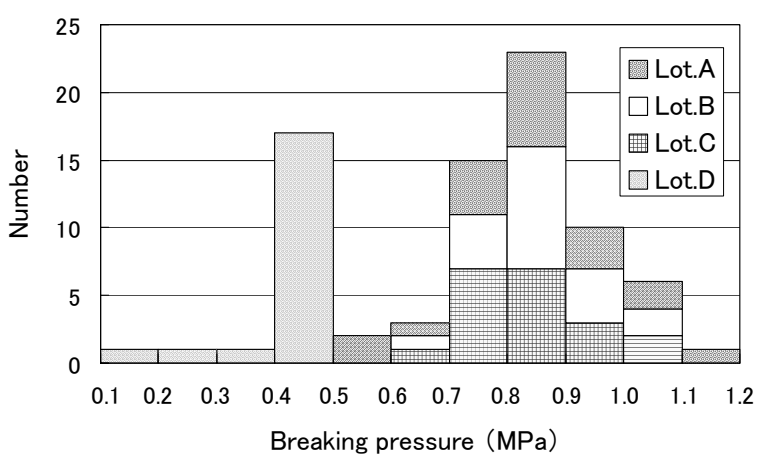

図 2 各種ロットでの破損耐圧

Fig. 2. Breaking pressure of each production lot.

発生しなくなった。このように本評価手法はプロセス条件 検討や工程管理という面でも有効である。

〈3·2〉 熱的信頼性 マイクロヒータは加熱して使用 するので, 当然ながら耐熱性は重要な評価項目である。特 にフローセンサや後で述べるマイクロガスセンサに使用す る場合, 僅かな抵抗変化が大きな誤差につながる危険性が あるので, 慎重な評価が要求される。

〈3·2・1〉 瞬時耐熱性 瞬間的な耐熱限界については, 徐々に印加電圧を上げて抵抗変化したり破損したりする電 圧を求め, 電圧一抵抗特性及び抵抗一温度特性から耐熱温 度に換算することで求められる。但し，ここでいうヒータ 温度についてはその定義を定めておく必要がある。通常の ヒータの場合, その温度は放射温度計や熱電対などで直接 ピーク温度を計測することが出来るが，マイクロヒータの 場合, 直接ピーク温度を測定することが難しい為, ヒータ 電圧と抵抗温度係数から求める場合が多い。この方法で得 られるヒータ温度はダイヤフラム内の平均的な温度を意味 することになり，ピーク温度はマイクロヒータの構造やヒ ータパターンによって異なってくる。以下の評価で用いた ヒータ温度については, 平均ヒータ温度で記述した。因み に評価に用いたマイクロヒータでは, FEM で推定したピー ク温度はこの平均温度の約 1.6 倍の温度となる。

開発したマイクロヒータの瞬間的な耐熱限界について は, 平均ヒータ温度で $800^{\circ} \mathrm{C}$ 以上であり, この状態でヒータ が赤熱していることを確認した。限界以上過熱した場合, 図 3 に示すように $\mathrm{Pt}$ ヒータの一部に剥離が発生し, 更に加 熱するとダイヤフラムが破壊した。尚, 開発段階で $\mathrm{Pt}$ 膜の 密着性が十分でない膜構成のものでは, $500^{\circ} \mathrm{C}$ 程度の低い温 度で, 通電直後に抵抗変化が起きるものもあった。又, $\mathrm{Pt}$ の密着層に金属を使用したタイプでは，加熱中にヒータの 


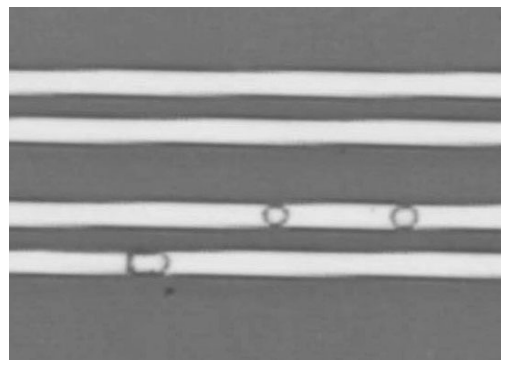

図 3 耐熱試験で剥離したマイクロヒータ

Fig. 3. De-lamination of the micro heater occurred by heat resistant evaluation.

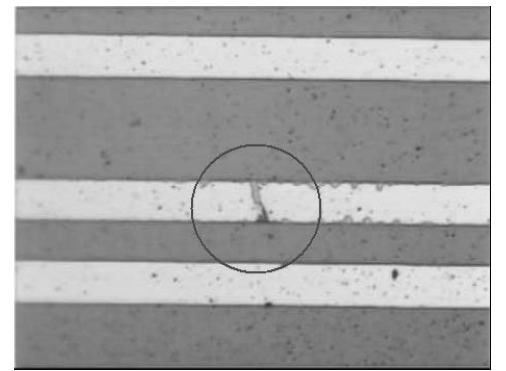

図 4 耐熱耐久試験で抵抗変化したマイクロヒータ

Fig. 4. Micro heater of which the resistance was changed by heat durability evaluation.

抵抗が徐々に変化した。これは加熱中に密着層の金属が $\mathrm{Pt}$ 中に拡散し Pt の抵抗值が変化した為である。以上より，耐 熱性のあるヒータを得る為には, Pt と基板の密着性が良好 でかつ拡散し難い密着層を選択することが重要となる。

〈3·2·2〉長期耐熱性実際の使用環境下では，長期 的な熱安定性の確保及び証明が重要な課題となる。長期の 加熱に対し，どのような劣化モードが起きるかを調査する 為, 各種ヒータ温度にて耐久試験を実施した。評価は平均 ヒータ温度で $500^{\circ} \mathrm{C}$ から $650^{\circ} \mathrm{C}$ まで行った。

$450^{\circ} \mathrm{C}$ 以下では $3000 \mathrm{hr}$ 後も抵抗值変化は発生しなかっ た。500 ${ }^{\circ} \mathrm{C}$ 上では耐久試験により抵抗変化が現れた。図 4 に抵抗変化が大きくなったヒータの拡大写真を示す。これ から判るように $\mathrm{Pt} の 一$ 部が消失しボイドとなっていた。こ れは抵抗変化したいずれのヒータにも見られた。更に耐久 を継続すると，最終的にはダイヤフラムは破壊しないまま の状態でヒータが断線した。これは明らかに耐熱試験のモ ードとは異なっていた。断線したヒータの断面を SEM で観 察したところ，断線部のすぐ横の Pt がわずかに厚くなって いることが観察された。この現象は Pt のエレクトロマイグ レーションによるものと推定される。すなわち高温で移動 しや寸くなった Pt 原子が電流方向に引っ張られ，最終的に 断線に到ったと考えられる(4)。

抵抗が $1 \%$ 変化した時間を寿命と定義した時の，耐熱耐久 試験でのワイブル分布を図 5 に示す。温度によらず傾きに は大きな差は認められず破損形態も同じであり，いずれの 温度でも同じモードで抵抗変化したと判断出来る。

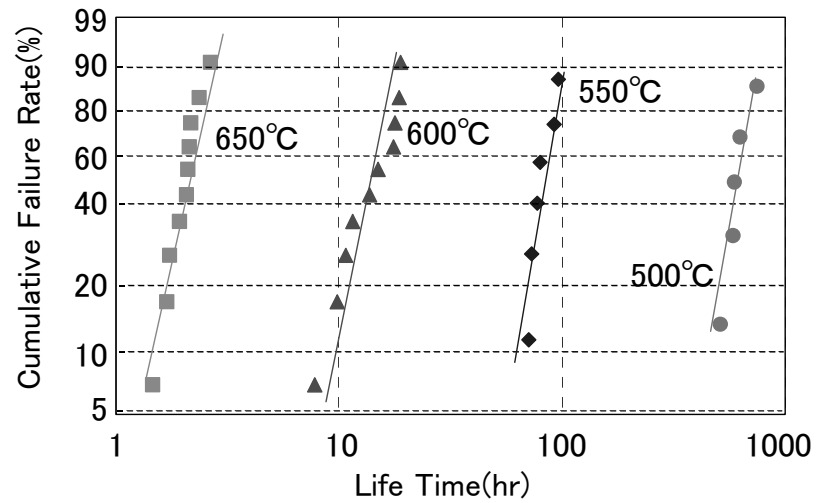

図 5 而熱耐久試験でのワイブル分布

Fig. 5. Weibull distribution of heat durability evaluation.

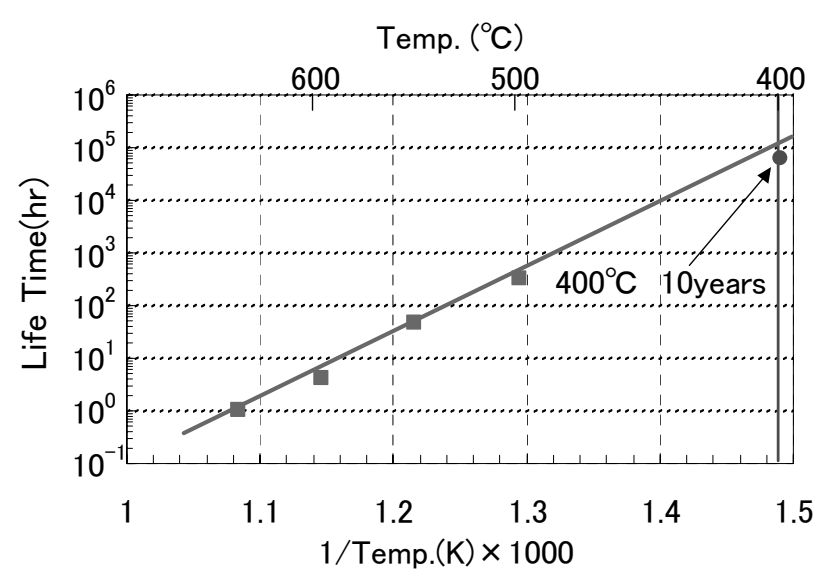

図 6 マイクロヒータのアレニウスプロット

Fig. 6. Arrhenius plots of the micro heater.

エレクトロマイグレーションでは, 温度と寿命の関係は 以下の式で現される(5)。

$$
\begin{aligned}
& \text { MTTF: 平均故障時間 } \\
& A: \text { 定数 } \\
& J \text { : } \\
& \quad \text { 電流密度 } \\
& n T \text { : 電流密度係数 } \\
& E a: \text { 活性化エネルギー } \\
& k: \text { ボルツマン定数 } \\
& T: \text { : 温度 }(\mathrm{K})
\end{aligned}
$$

この式を用いて実使用温度でのヒータ寿命を算出した。 ワイブルプロットより各温度での故障発生確率 $1 \%$ となる 寿命時間を求め, アレニウスプロットを行った。眓 6 にそ の結果を示す。この図から推定される寿命としては, フロ 一センサやマイクロガスセンサとして適用想定している実 使用温度 $400^{\circ} \mathrm{C}$ 以下において, 連続通電で 10 年以上という 十分な耐熱耐久性があることが示された。

〈3·2·3〉 ON-OFF 耐性起動停止, あるいは温度モ ジュレーション的な使用を想定して, ON-OFF 耐久性を評 価した。マイクロヒータでは非常に高速に昇降温出来るた め, 比較的短時間で ON-OFF 耐久性を確認することが出来 る。ここでは $50 \mathrm{msec}$ 毎に ON-OFF を行った。

使用想定温度である $400^{\circ} \mathrm{C}$ に対し， $500^{\circ} \mathrm{C}$ で 10 の 8 乗サ 
イクルの耐久試験を実施し，十分な ON-OFF 而性があるこ とを確認した。

〈3.3〉 被水耐性車載用センサでは設置場所によっ ては結露したり被水することが考えられる。開発したマイ クロヒータは常時大量結露するような環境下で使用するこ とを想定しているものではないが，サバイバル条件として はこうした被水に対する耐性を持つことが望まれる。

そこで, マイクロヒータを被う程度の量の水滴を垂らし た状態で $400^{\circ} \mathrm{C}$ 相当の電圧を印加する試験, および $400^{\circ} \mathrm{C} に$ 加熱した状態で水滴を垂らす試験を各々 100 回ずつ実施し た。マイクロヒータは熱容量が小さく加熱エネルギーも低 い為, 水滴を垂らした瞬間に温度が大きく低下寸るが， ヒ 一夕には異常は見られなかった。

\section{4. 車載用センサへの応用}

〈4・1〉 エアフローメータマイクロヒータを使った 車載用センサとして実用化されているものにエアフローメ ータがある(2)(3)。マイクロヒータを使ったフローセンサは検 知部の熱容量が極めて小さいため低消費電力で応答性が優 れており, 更には順流逆流の双方向流量検出も可能となる。 エンジンの吸入空気流は流量変動が激しく逆流を含む大き な脈動流であり，この環境下で脈動流の平均流量を高い精 度で検出するために，上記特徵は大変都合の良いものであ る。

一方で車載用エアフローメータの使用環境は非常に苛酷 で，エアクリーナーを通過したダストが検知素子に衝突し たり, 設置場所によってはカーボンやオイルミストに唒さ れる。これらはダイヤフラムの破損や流量特性の変化を引 き起こす原因になるため, 実環境での信頼性を保証する評 価が重要となる。

図 7 に試作したエアフローメータを示す。ダイヤフラム 内に設けた 2 本のヒータを直列接続し，その合計の平均温 度が環境温度に対し常に一定温度差になるように制御し， 2 本のヒータの温度差から順流逆流の双方向流量を検出寸る 方式のもので, $10 \mathrm{msec}$ オーダーの脈動に追従出来る。この センサをエンジンの吸気管に取り付けてエンジン始動させ た時の出力波形を図 8 に示す。クランキング時及び燃焼開 始時の脈動流が捉えられている。なお, 本センサではダス 卜などの耐異物性を向上するためと脈動下での流量測定精 度を改善する目的で, 分流路方式を採用している(6)。

$\langle 4 \cdot 1 \cdot 1\rangle$ 異物衝突試験 ダストなどの異物衝突の加 速試験として, センサを $\phi 35 \mathrm{~mm}$ の取付管に設置し, 約 $15 \mathrm{~cm}$ 直上より JIS 1 種粉体（ケイ砂，中位径 $200 \mu \mathrm{m}$ ）を ノズルから連続的に $10 \mathrm{~g} / \mathrm{hr}$ 投入した。流速は約 $10 \mathrm{~m} / \mathrm{sec}$ で 実施し, 破損するまでの時間を調べた。比較として検知素 子が主流路に直接暴露しているタイプ（直接流式）と，マ イクロヒータを用いた市販の自動車用エアフローメータに ついても試験を行った。試験は各 3 ケで結果を表 2 に示す。 検知素子が主流路に直接暴露している直接流式と市販工 アフローメータは数秒から数分で破損するに対し, 分流路

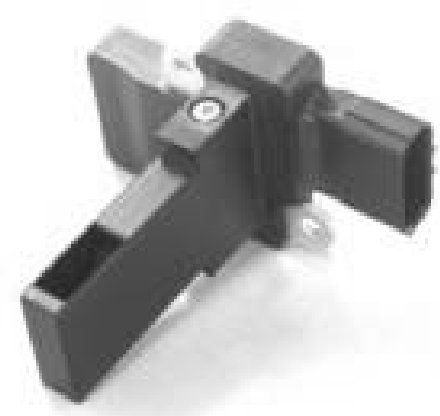

図 7 エアフローメータ外観

Fig. 7. Photograph of the developed air flow meter.

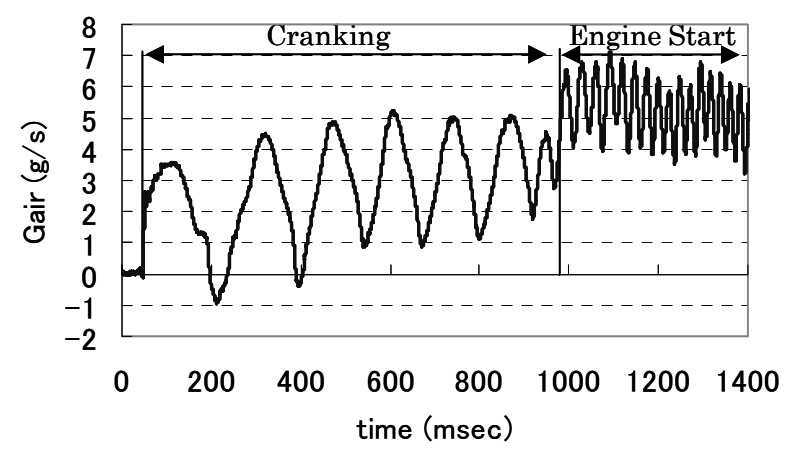

図 8 エンジン始動時のセンサ出力

Fig. 8. Sensor output at engine start.

表 2 各種センサの異物衝突試験

Table 2. Evaluation for foreign collision.

\begin{tabular}{|c|c|c|c|}
\hline $\begin{array}{c}\text { Sensor } \\
\text { Type }\end{array}$ & $\begin{array}{c}\text { Commercial } \\
\text { sensor }\end{array}$ & $\begin{array}{c}\text { Direct flow } \\
\text { type (NTK) }\end{array}$ & $\begin{array}{c}\text { Bypass flow } \\
\text { type (NTK) }\end{array}$ \\
\hline $\begin{array}{c}\text { Broken } \\
\text { time }\end{array}$ & $\sim 10 \mathrm{sec}$ & $30 \sim 150 \mathrm{sec}$ & $3 \sim 5 \mathrm{hr}$ \\
\hline
\end{tabular}

をつけたエアフローメータでは $1 \mathrm{hr}$ 以上破損しなかった。 これは, 分流路の入り口で急峻に流れ方向が変わることに より異物が慣性で分流路に入り難くなって, 結果として素 子表面にやってくる異物が減ったためと考えられる。図 9 に分流路の形状と異物の流れを模式的に示寸。

本試験は, 実際のエアクリーナーを通過するダストに対 して非常に厳しい条件であり, その妥当性には議論の余地 があろうが，素子だけで耐異物性を向上させようとすると， ダイヤフラムの厚みを増したりサイズを小さくすることに なり, 応答性や検出性能を低下させることになるので, フ ローセンサを使いこな寸上で分流路設計などセンサ全体で の適用化技術が非常に重要となる。この他, カーボンやオ イルミストの付着劣化に対しても市場要求を満たす必要が あり, 総合的な性能が重要となる。

〈4·2〉空気質センサ 車載用ガスセンサでは, 排気 ガスの $\mathrm{A} / \mathrm{F}$ を測定してフィードバック制御する酸素セン サ(7)(8)が有名であるが, 排気系は高温で非常に厳しい環境で あるため, まだ MEMS センサの実用例はない。他のガスセ ンサとしては空調制御用の空気質センサがあり, 車外の排 気ガスの有無を検知して, 外気導入と内気循環を自動で切 


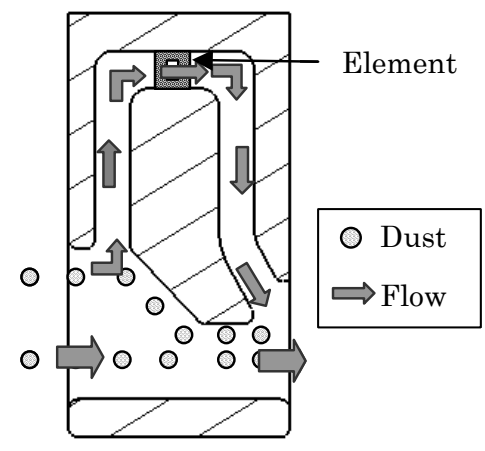

図 9 分流路形状と異物流れモデル

Fig. 9. Schematic view of the bypass flow and a model of dust and flow paths.

り替えるシステムが実用化されている(9)。

空気質センサは，排気ガス中に含まれる $\mathrm{NO}_{\mathrm{x}}$ や $\mathrm{CO}$ を酸 化物半導体との酸化還元反応を利用して検出するものであ り，ガス反応を活性化するためヒータを内蔵している。一 般的にはアルミナ基板にヒータとガス感応膜を厚膜形成し たタイプが主流であるが，近年，マイクロヒータを使った MEMS ガスセンサ(10)が検討されており, 小型で消費電力が 少なく，熱影響範囲が狭いのでマルチ素子化が容易となる。

図 10 に製作した空気質センサ素子とセンサュニットを示 す。センサ素子はマイクロヒータの上に検知電極を設け, $\mathrm{SnO}_{2}$ 酸化物半導体と貴金属触媒を形成している。 $\mathrm{NO}_{\mathrm{x}}$ と

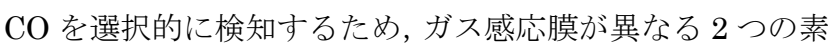
子を，1 つのセラミックパッケージに実装している。この MEMS ガスセンサ素子を用いることで, 従来のセンサユニ ットと比較して体積で約 $1 / 3$ と小型化出来た。

図 11 に実車に装着して市街を走行した時のセンサ出力を 示す。同時に分析計の出力も併せて計測したが，MEMS ガ スセンサは既存品とほぼ同様に, $\mathrm{NO}_{\mathrm{x}}$ と $\mathrm{CO}$ ガスの濃度に 応じた出力を示した。なお，これら酸化物半導体センサで は, 抵抗の絶対值や温湿度などの影響を受けるため, 素子 抵抗の変化からこの影響を演算補正し，ダンパーの開閉信 号を作っている(11)。

MEMS ガスセンサの信頼性評価としては, 通常のガスセ ンサ同様，耐熱性や耐湿性および而振性などがあげられる が, 従来の厚膜感応膜に対して薄膜構造となるため, 材料 の安定性や密着性については注意が必要となる。又, ガス センサの場合, 被毒による触媒失活によって出力劣化する ことが懸念されるので, 市場モードを想定した上で適切な 加速試験の設定が必要となる。

開発した空気質センサにおいても，耐熱・耐湿・耐振試 験などとともに，被毒ガスに対する影響を評価し，実車耐 久試験の結果と擦り合せを行っている。

\section{5. まとめ}

車載用センサに使用する $\mathrm{Pt}$ 薄膜とダイヤフラム構造から なるマイクロヒータを開発し，その信頼性評価を行った。

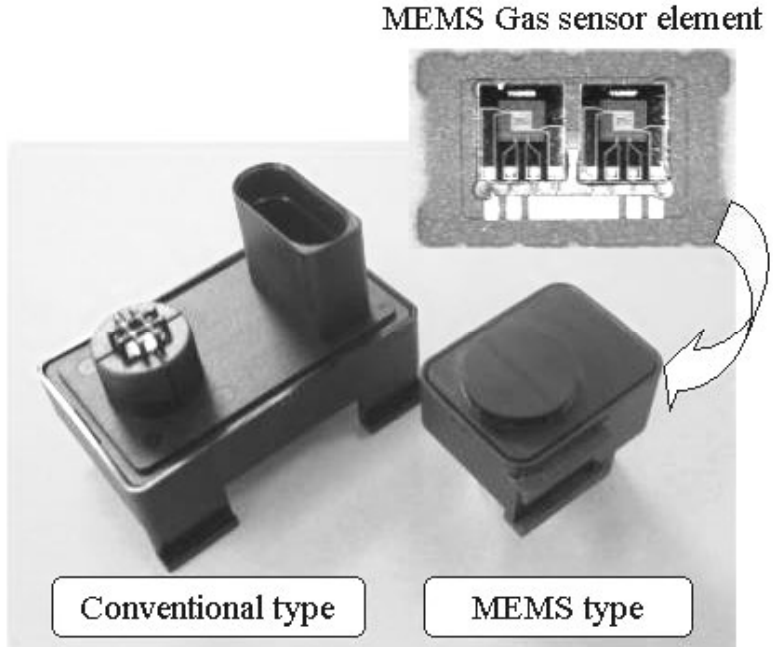

図 10 空気質センサ素子とセンサユニット外観

Fig. 10. Photographs of the developed air quality sensor element and sensor units.
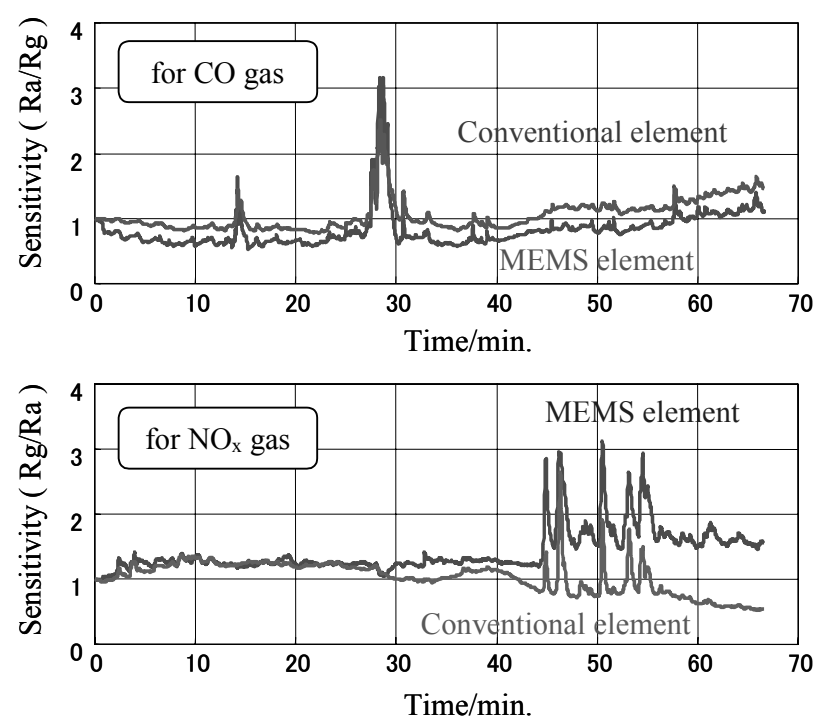

図 11 空気質センサ素子の出力例（実車試験）

Fig. 11. Output examples of Road tests of the air quality sensor.

機械的強度では, 圧力印加法によりダイヤフラム膜構成 の検討やプロセス妥当性の評価に有効であることを示し た。熱的信頼性では, 瞬間的な過熱に対しては剥れが支配 的であること, 長期的な耐熱性に対してはエレクトロマイ グレーションが支配的であることを見出し，これから推定 した寿命は, ヒータ平均温度 $400^{\circ} \mathrm{C}$ (ピーク温度で $600^{\circ} \mathrm{C}$ 以

上）で連続加熱 10 年以上の耐久性を示した。

このマイクロヒータを使った車載用センサとして, エア フローメータと空気質センサについて, その特徴とともに アプリケーション特有の評価について述べた。今後, より 信頼性を高め耐久デー夕を積み上げることで, 車載用途だ けでなく更に多くの分野への応用が期待される。

(平成 17 年 11 月 25 日受付, 平成 18 年 4 月 17 日再受付) 


\section{文献}

(1) D. Eddy and D. Sparks : "Application of MEMS Technology in Automotive Sensors and Actuators", Proc. of the IEEE, Vol.86, No.8, pp.1747-1755 (1998-8)

(2) U. Konzelmann, H. Hecht, and M. Lembke : "Breakthrough in Reverse Flow Detection - A New Mass Air Flow Meter Using Micro Silicon Technology", SAE Paper950433 (1995)

(3) H. Nakamura, M. Taruya, and K. Tanimoto : "Miniaturization of Sensor for Engine Control System", Mitsubishi Electric Tech. J., Vol.78, No.9, pp.23-26 (2004-9) (in Japanese) 中村洋志・樽谷公昭・谷本考司：「エンジン制御用センサの小型化」, 三菱電機技報, Vol.78, No.9, pp.23-26 (2004-9)

(4) F. M. D' Hearle : "Electromigration and Failure Electronics : An Introduction", Proc. of the IEEE, Vol.59, No.10 (1971-10)

（5）半導体標準化委員会:「LSI の故障メカニズムに基づいた信頼性試験 方法」，日本電子機械工業会規格，EIAJ ED-4704 (2000)

(6) Y. Nishimura and K. Uchiyama : "Intake Air Measurement Technique for Automotive Engine", T. IEE Japan, Vol.118-E, No.6, pp.300-303 (1998-6) (in Japanese)

西村 豊・内山 薫: 「自動車エンジンの吸入空気量計測技術」, 電 学論 E, 118, 6, pp.300-303 (1998-6)

(7) T. Yamada, N. Hayakawa, Y. kami, and T. Kawai : "Universal Air-Fuel Ratio Heated Exhaust Gas Oxygen Sensor and Further Applications", SAE Paper920234 (1992)

(8) T. Yamada, A. Mizutani, T. Kawai, M. Nasu, and T. Okawa : "Application of Oxygen Sensor for Air Fuel Feed Back Control of Internal Combustion Engine", J. of Soc. of Automotive Eng. of Japan, Vol.56, No.4, pp.22-27 (2002-4) (in Japanese) 山田哲正・水谷昭夫 ・川合 尊・那須峰次・大川哲平：「内燃機関用 空燃比フィードバックセンサ」, 自動車技術，56, 4, pp.22-27 (2002-4)

(9) K. Oto, T. Nakahara, and I. Asoh : "Automatic Ventilation Control System for Automobile”, T. IEE Japan, Vol.118-E, No.2, pp.68-71 (1998-2)

大戸亀久美・中原 毅・麻生 功：「自動車用内外気自動切り替えシ ステム」, 電学論 $\mathrm{E}, 118,2$, pp.68-71 (1998-2)

(10) V. Demarne and A. Grisel : "An Integrated Low-Power Thin Film CO Gas Sensor on Silicon", Sensors and Actuators, 13, pp.301-313 (1988)

(11) S. Ito, Y. Iwasaki, Y. Kimoto, K. Hirai, Y. Koyama, and T. Matsuoka : "Development of Air Quality sensor", SAE Paper 2002-01-1081 (2002)

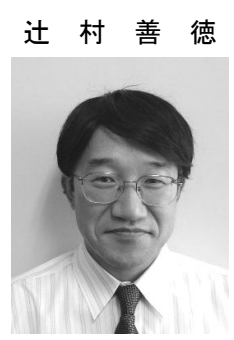

（非会員） 1961 年 11 月 14 日生。 1985 年 3 月金沢大学大学院電子工学専攻修士課程修了。 1997 年 5 月日本特殊陶業㑣入社。主として MEMS プロセス及びセンサ回路の開発に従 事。現在，総合研究所主任。

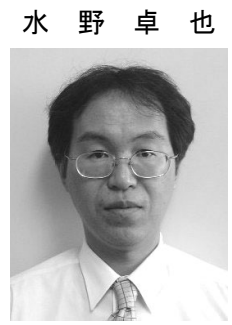

（正員） 1969 年 10 月 23 日生。 1995 年 3 月 岐阜大学大学院電子情報工学科前期博士課程 修了。同年 4 月 日本特殊陶業(株)入社。主とし て MEMS センサの開発に従事。現在, 総合研 究所主任。

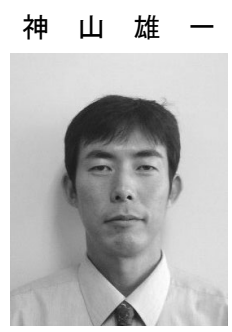

（非会員） 1967 年 6 月 14 日生。 1990 年 3 月 名古屋工業大学電気情報工学科卒業。同年 4 月 日本特殊陶業(森入社。主として車載用センサ, MEMS ガスセンサの開発に従事。現在, 総合 研究所主任。

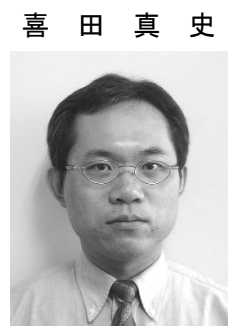

(非会員) 1965 年 11 月 25 日生。 1991 年 3 月名古屋工業大学大学院物質工学専攻博士前 期課程修了。1996 年 7 月日本特殊陶業(株入社。 主としてガスセンサの材料開発に従事。現在, 総合研究所主任。

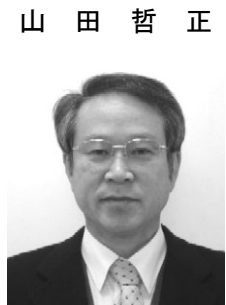

（非会員） 1949 年 7 月 22 日生。 1974 年 3 月 名古屋工業大学工学研究科修士課程修了。同 年, 日本特殊陶業(森入社。主として車載用排気 ガスセンサの開発に従事。センサ事業部技術部 長を経て, 現在, 取締役総合研究所部長。工学 博士。 